\title{
Isolation and Characterization of Arcobacter butzleri from Environmental Samples and Determination of their Pathogenic Gene Expression under Different Physicochemical Conditions
}

\author{
Sara Fallahchay ${ }^{1}$, Nima Bahador ${ }^{1 *}$, Masood Ghane ${ }^{2}$ \\ ${ }^{1}$ Department of Microbiology, College of Sciences, Shiraz Branch, Islamic Azad University, Shiraz, Iran \\ ${ }^{2}$ Department of Microbiology, Tonekabon Branch, Islamic Azad University, Tonekabon, Iran
}

Received, 27 August 2020

Accepted, 30 November 2020

\begin{abstract}
Being transmitted through food and water, Arcobacter butzleri (A. butzleri) is known as an emerging pathogenic microorganism in humans. This Campylobacter-like organism can cause infertility, miscarriage, as well as gastrointestinal (GI) disorders in animals and even lead to gastroenteritis, bacteremia, endocarditis, and peritonitis in humans. To meet the research objectives, a total number of 384 samples were collected from the wastewater discharged by a poultry slaughterhouse $(\mathrm{n}=238)$ and the Cheshmeh Kileh River (146) in the city of Tonekabon, northern Iran, during the four seasons of the year. Then, the samples were evaluated using culture techniques and phenotyping. In addition, the polymerase chain reaction (PCR) was applied to confirm A. butzleri via 16S ribosomal ribonucleic acid (rRNA) sequencing and pathogenic genes, i.e., tlyA, ciaB, and mviN. Afterwards, the effect of various environmental stresses on the isolates was evaluated. Finally, the reverse transcription (RT)-PCR was exploited to reflect on expression/lack of expression of the pathogenic genes at pre-/post-shock stages. Totally, 58 isolates were established as A. butzleri, which contained three pathogenic genes out of all three strains. The effect of various environmental stresses on tlyA, mviN, and ciaB expressions also demonstrated discontinued expression at $\mathrm{pH}$ levels of 5.0,6.0, and 9.0; 5\% sodium chloride (salt, $\mathrm{NaCl}$ ) concentration; and $90 \mathrm{~s}$ ultraviolet (UV) light exposure time. In addition, the expressions of tlyA and ciaB stopped at 20 and $40^{\circ} \mathrm{C}$ while no temperature affected the expression of mviN.
\end{abstract}

Keywords: Arcobacter butzleri, environmental stress, virulence gene, phylogenetic analysis

*e-mail: bahador@iaushiraz.ac.ir 


\section{Introduction}

Arcobacter butzleri (A. butzleri) is known as a Gram-negative, curved, spiral-shaped, non-sporeforming, and motile bacterium of the family Campylobacteraceae [1]. This microorganism causes infertility, miscarriage, as well as gastrointestinal (GI) disorders in animals and even leads to gastroenteritis, bacteremia, endocarditis, and peritonitis in humans [2]. In addition, A. butzleri may induce septicemia, abdominal cramp-like pains, and chronic diarrhea for more than two months $[3,4]$. A. butzleri, as the most common species, is widely found in water, which is the source of animal food. In addition, it is usually isolated from a variety of environments such as beef, pork, poultry, lettuce, water and drainage tanks, milk and animal feces $[5,6]$.

In this regard, obvious resistance of $A$. butzleri along with its ability to survive and grow in aerobic conditions augments its potential as a food- and waterborne pathogen. On the other hand, its adaptability to stressful situations may later make it resistant to the same or other types of stress, and this exposure to multiple stresses during its lifecycle in the food strain can create the possibility of its survival [7]. Indeed, A. butzleri strains can tolerate high levels of sodium chloride (salt: $\mathrm{NaCl}$ ) and grow at low temperatures. In addition, they can adhere to a variety of surfaces, and all of these features may justify the presence of these bacteria in food $[8,9]$. Today, there is a strong interest in developing an assortment of mathematical models for environmental issues including food, oxygen, water, $\mathrm{pH}$, temperature, and effective preservatives shaping the growth, survival, and inactivation of bacteria. Previously, there were a few mathematical models to improve food durability and safety through regulating environmental factors [1]. However, little is known about the pathogenic mechanisms and the pathogenic genes of $A$. butzleri. On the other hand, determining the RM4018 genome sequence of $A$. butzleri has verified the presence of 10 pathogenic genes of cadF, $m v i N$, pldA, tly $A$, cj1349, hecB, irgA, hecA, ciaB, and iroE [10-12]. Nevertheless, it is not still clear whether the pathogenic factors are characterized by similar functions for their homologs in other bacterial species or not [4]. Given the importance of pathogenic genes, the present study was to isolate $A$. butzleri from environmental samples, to determine the presence of $c i a B$, contributing to host cell invasion via the secretory system, tly $A$, and encoding hemolysin and $m v i N$ as an essential protein required for peptidoglycan biosynthesis, and ultimately to evaluate their survival rates and expressions under different physicochemical conditions.

\section{Materials and Methods}

\section{Isolation and Identification of $A$. butzleri Strains}

A total number of 384 samples were collected, including 238 cases from the wastewater discharged by a poultry slaughterhouse and 146 cases from the Cheshmeh Kileh River in the city of Tonekabon, northern Iran. The samples were then cultivated onto the Preston medium, enriched with supplements, and incubated at $25^{\circ} \mathrm{C}$ for $24 \mathrm{~h}$. Afterwards, the given samples were inoculated onto Campylobacter Selective Agar (CAMPY), enriched with defibrinated sheep blood and Campylobacter supplement. Subsequently, the plates were incubated at $25^{\circ} \mathrm{C}$ for $48-72 \mathrm{~h}$. The suspected $A$. butzleri colonies were also identified using Gram staining, catalase, fermentation of glucose, lead (II) acetate $\left(\mathrm{Pb}\left(\mathrm{CH}_{3} \mathrm{COO}\right)_{2}\right)$, nitrate $\left(\mathrm{NO}_{3}^{-}\right)$reduction reaction, urease, growth in $1 \%$ glycine, increase in $3.5 \% \mathrm{NaCl}$, as well as resistance to nalidixic acid (NA: $\mathrm{C}_{12} \mathrm{H}_{12} \mathrm{~N}_{2} \mathrm{O}_{3}$ ) and Cephalothin as an antibiotic [13].

\section{Molecular Identification of $A$. butzleri}

For the purpose of molecular identification, deoxyribonucleic acid (DNA) was extracted according to the cDNA synthesis kit (GeneAll extraction kit, Korea). In addition, the $16 \mathrm{~S}$ ribosomal ribonucleic acid (rRNA) gene and the virulence genes of $m v i N, c i a B$, and tlyA of $A$. butzleri were identified using their specific primers (Table 1). Each polymerase chain reaction

Table 1. Forward/reverse primer sequences for 16s RNA gene and pathogenic genes of $A$. butzleri

\begin{tabular}{|c|c|c|c|c|}
\hline Name of Primer & Sequence $\left(5^{\prime} \rightarrow 3^{\prime}\right)$ & Target gene & Amplicon length & Reference \\
\hline Arcol & GTCGTGCCAAGAAAAGCCA & \multirow{2}{*}{$16 \mathrm{~S}$ rRNA } & \multirow{2}{*}{$1.223 \mathrm{bp}$} & \multirow{4}{*}{$\begin{array}{l}\text { (Douidah et al. } \\
\text { 2012; Tabatabaei } \\
\text { et al. 2014) }\end{array}$} \\
\hline $\operatorname{Arco} 2$ & GGTGTAGGATGAGACTATATA & & & \\
\hline CiaB-F & TGGGCAGATGTGGATAGAGCTTGGA & \multirow{2}{*}{$C i a B$} & \multirow{2}{*}{284 bp } & \\
\hline CiaB-R & TAGTGCTGGTCGTCCCACATAAAG & & & \\
\hline$M v i N-\mathrm{F}$ & TGCACTTGTTGCAAAACGGTG & \multirow{2}{*}{$M v i N$} & \multirow{2}{*}{294 bp } & \multirow{4}{*}{$\begin{array}{l}\text { (Douidah et al. } \\
\text { 2012; Tabatabaei } \\
\text { et al. 2014) }\end{array}$} \\
\hline$M v i N-\mathrm{R}$ & TGCTGATGGAGCTTTTACGCAAGC & & & \\
\hline$T l y A-\mathrm{F}$ & CAAAGTCGAAACAAAGCGACTG & \multirow{2}{*}{$\operatorname{Tly} A$} & \multirow{2}{*}{$230 \mathrm{bp}$} & \\
\hline$T l y A-\mathrm{R}$ & TCCACCAGTGCTACTTCCTATA & & & \\
\hline
\end{tabular}


(PCR) amplification was correspondingly carried out via a $20 \mu \mathrm{l}$ reaction mixture containing $10 \mu \mathrm{l}$ of Master Mix (HotStartTaq Polymerase, dNTP, buffer, Mgcl), $1 \mu \mathrm{l}$ of forward primer, $1 \mu \mathrm{l}$ of reverse primer, $3 \mu \mathrm{l}$ of distilled water, and $5 \mu \mathrm{l}$ of DNA for the desired gene.

The cycling conditions were initial denaturation at $94^{\circ} \mathrm{C}$ for $4 \mathrm{~min}$ followed by 25 cycles of denaturation at $94^{\circ} \mathrm{C}$ for $1 \mathrm{~min}$, annealing at $56^{\circ} \mathrm{C}$ for $1 \mathrm{~min}$ and $72^{\circ} \mathrm{C}$ for $1 \mathrm{~min}$, and extension at $72^{\circ} \mathrm{C}$ for $7 \mathrm{~min}$. In addition, the cycling condition for $m v i N$ and ciaB gene were $94^{\circ} \mathrm{C}$ for $3 \mathrm{~min}$ followed by 35 PCR cycles of denaturation at $94^{\circ} \mathrm{C}$ for $45 \mathrm{~s}, 56^{\circ} \mathrm{C}$ for $45 \mathrm{~s}$, and $72^{\circ} \mathrm{C}$ for $45 \mathrm{~s}$, and the final extension at $72^{\circ} \mathrm{C}$ for $10 \mathrm{~min}$. For $\operatorname{tly} A$, the thermacycler instrument was set at $94^{\circ} \mathrm{C}$ for $3 \mathrm{~min}$ for initial denaturation. Afterwards, 35 PCR cycles included $94^{\circ} \mathrm{C}$ for $45 \mathrm{~s}, 55^{\circ} \mathrm{C}$ for $45 \mathrm{~s}$, and $72^{\circ} \mathrm{C}$ for $45 \mathrm{~s}$, and the final extension at $72^{\circ} \mathrm{C}$ for 10 min [12-14]. Ultimately, the PCR products were subjected to electrophoresis with $1.5 \%$ agarose gel, stained with ethidium bromide (C21H20BrN3), and then photographed under a gel documentation system. Subsequently, the amplicons were purified and sent for direct sequencing to Sequetech Corporation. The pathogenic gene expression of $t l y A, c i a B$, and $m v i N$ was assessed applying the cDNA synthesis kit (GeneAll extraction kit, Korea) based on PCR and specific primers.

\section{Effect of Various Environmental Stresses on Isolates}

To this end, the identified bacteria were incubated in $25 \mathrm{ml}$ of the pre-made Preston medium and then kept at $25^{\circ} \mathrm{C}$ for $48 \mathrm{~h}$. Then, turbidity level was assessed with the 0.5 McFarland standards. Subsequently, $1 \mathrm{ml}$ of the samples was transferred to the Preston medium with various $\mathrm{pH}$ levels of 5.0, 6.0 (citrate buffer), 7.0, 8.0 (barbital buffer), and 9.0 (glycine buffer) and incubated at $25^{\circ} \mathrm{C}$ for $24 \mathrm{~h}$. The bacterial growth was additionally evaluated before and after the shocks using turbidity meter and spectrophotometry. The same procedure was further completed for the effect of different temperatures (namely, 20, 25, 30, 35, and $\left.40^{\circ} \mathrm{C}\right)$ [2] as well as $\mathrm{NaCl}$ concentrations $(1 \%, 3 \%$, and $5 \%$ ) [1]. To evaluate the effect of the ultraviolet (UV) light exposure, the inoculates placed in empty plates were set at a distance of $34 \mathrm{~cm}$, below the UV device with a wavelength of $250 \mathrm{~nm}$, at 30,60, 90, and $120 \mathrm{~s}$ [15]. Then, the samples were cultivated onto CAMPY under sterile conditions and kept at $25^{\circ} \mathrm{C}$ for $48 \mathrm{~h}$. Following the evaluation of different environmental stresses, the reverse transcription (RT)-PCR was recruited to reflect on the expression of the pathogenic genes [8].

\section{Results and Discussion}

\section{Isolation, Identification and Occurrence of the Isolates}

Totally, 58 samples were confirmed according to A. butzleri phenotyping. As shown in Table 2, most of the isolates belonged to springtime and the samples extracted from the poultry slaughterhouse wastewater $(34.48 \%)$. However, fewer isolates were related to the winter with an occurrence rate of $5.17 \%$ in the samples obtained from the poultry slaughterhouse wastewater and no strains had been isolated from the Cheshmeh Kileh River.

\section{Molecular Identification of Isolates}

The isolates in this study were molecularly confirmed based on the 16S rRNA gene sequencing and they showed pieces 1.223 base pair (bp) (Fig. 1). Furthermore, all the three isolated strains (100\%) demonstrated the presence of ciaB (284 bp) (Fig. 2), mviN (294 bp) (Fig. 3), and tlyA (230 bp) genes (Figure 4). According to the results obtained from the National Center for Biotechnology Information (NCBI), the first isolate belonged to A. butzleri strain NCTC (LT906455.1) with 93\% homology. As well, the second and the third isolates were recognized as A. butzleri JV22 (CP040507.1) and A. butzleri ED-1 (AP012047.1) with $97 \%$ and $99 \%$ similarity, respectively.

\section{Effect of Various Environmental Stresses on Isolates}

The impact of various environmental stresses in the present study was assessed on the bacterial growth

Table 2. Number/frequency of A. butzleri strains isolated from the Cheshmeh Kileh River and poultry slaughterhouse wastewater.

\begin{tabular}{|c|c|c|c|c|}
\hline Seasons & Sample collection & Number of isolates & $\begin{array}{c}\text { Number of isolates from } \\
\text { Cheshmeh Kileh River }\end{array}$ & $\begin{array}{c}\text { Number of isolates from poultry } \\
\text { slaughterhouse wastewater }\end{array}$ \\
\hline Spring & 139 & $25(6.5 \%)$ & $5(8.62 \%)$ & $20(34.48 \%)$ \\
\hline Summer & 99 & $10(2.6 \%)$ & $2(3.44 \%)$ & $8(13.79 \%)$ \\
\hline Fall & 89 & $20(5.2 \%)$ & $9(15.51 \%)$ & $11(18.96 \%)$ \\
\hline Winter & 57 & $3(0.7 \%)$ & - & $3(5.17 \%)$ \\
\hline Total & 384 & $58(15.1 \%)$ & $16(27.57 \%)$ & $42(72.4 \%)$ \\
\hline
\end{tabular}




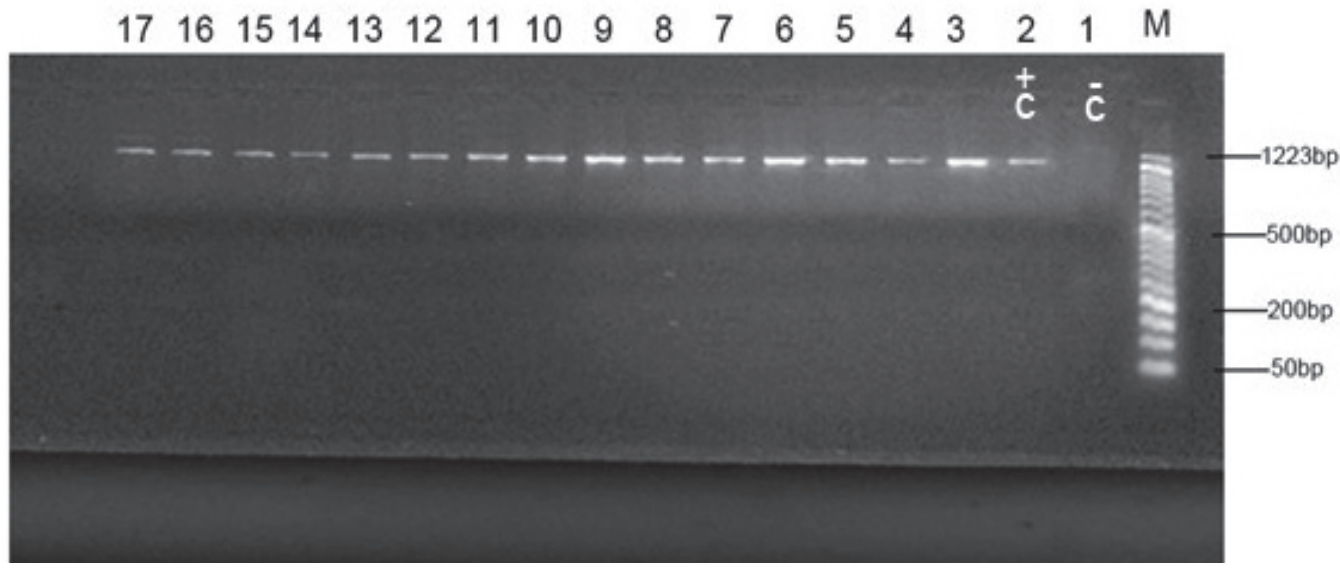

Fig. 1. Results of PCR on 1.5\% agarose gel, Lane 1, negative control, Lane 2, positive control (a strain confirmed in previous studies), Lanes 3-17, samples of $A$. butzleri isolated. M, Marker (1.5-kilo bp).

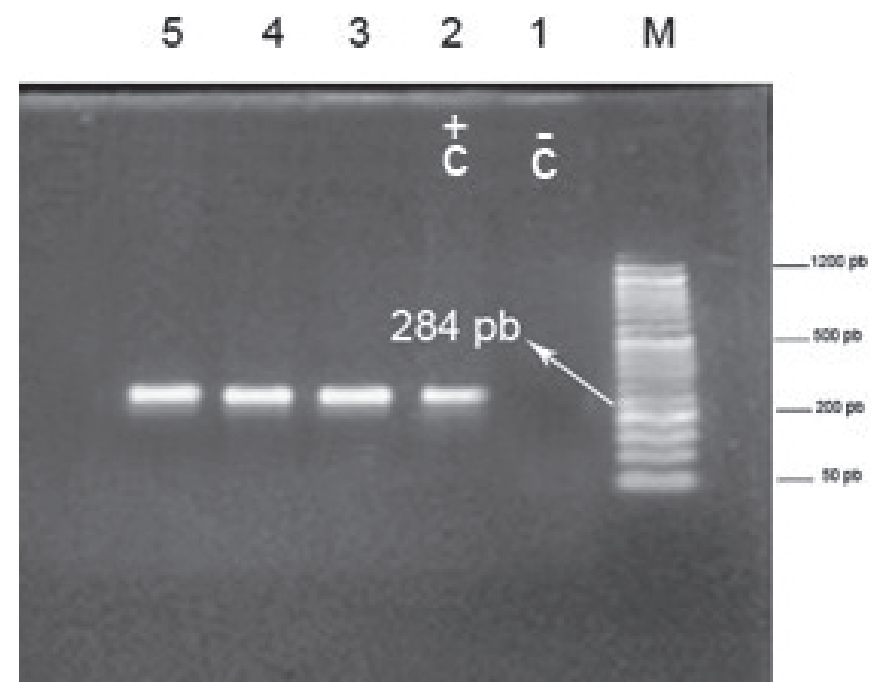

Fig. 2. Results of PCR on 1.5\% agarose gel, Lane 1, negative control, Lane 2, positive control (a strain confirmed in previous studies), Lanes 3-5, one-third of samples of $A$. butzleri that contained the ciaB gene. M, Marker (1.5-kilo bp).

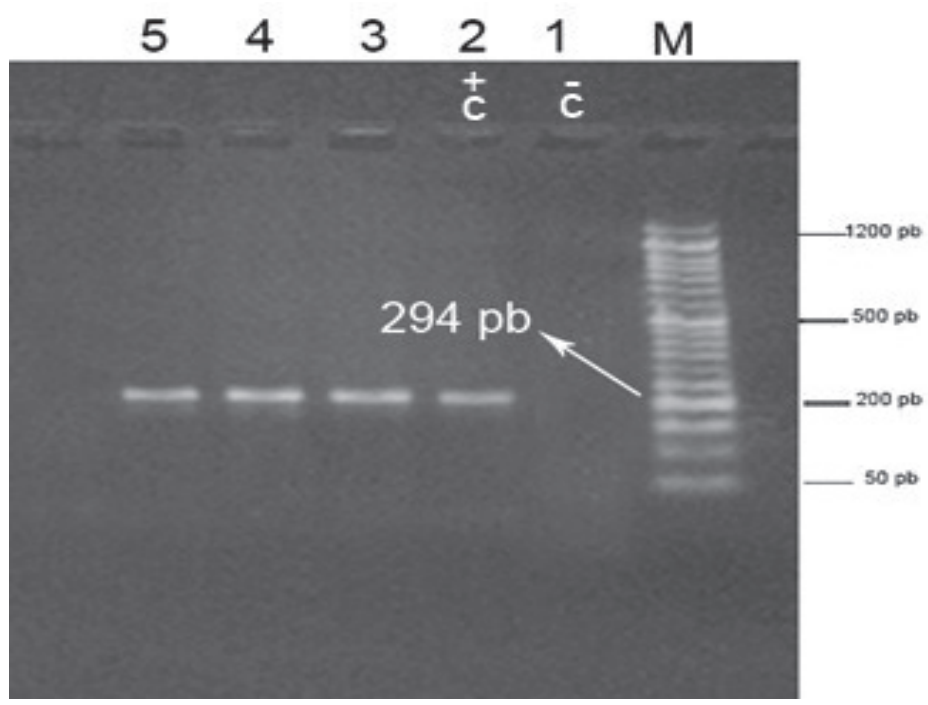

Fig. 3. Results of PCR on 1.5\% agarose gel, Lane 1, negative control, Lane 2, positive control (a strain confirmed in previous studies), Lanes 3-5, one-third of samples of $A$. butzleri that contained the $m v i N$ gene. M, Marker (1.5-kilo bp). 
rate at the time of inoculation and $24 \mathrm{~h}$ later. The data analysis was further performed using the SPSS Statistics software (version 22) through descriptive (frequency, frequency percentage, mean, and standard deviation (SD) and inferential (paired-samples t-test and one-way analysis of variance (ANOVA) statistics. In this resepct, the paired-samples t-test results regarding the effect of various $\mathrm{pH}$ levels on the bacterial growth rate before and $24 \mathrm{~h}$ later revealed a significant difference between the $\mathrm{pH}$ levels of 5.0, 7.0, 8.0, and $9.0(\mathrm{p}<0.05)$. In addition, the bacterial growth rate decreased $24 \mathrm{~h}$ following inoculation at a $\mathrm{pH}$ level of 5.0 but elevated at the $\mathrm{pH}$ levels of 7.0, 8.0, and 9.0. Moreover, the results of one-way ANOVA established a significant difference in the bacterial growth rate at the mentioned $\mathrm{pH}$ levels during inoculation and $24 \mathrm{~h}$ later $(\mathrm{p}<0.05)$. All through inoculation, the highest level of bacterial growth was related to the $\mathrm{pH}$ level of 7.0, whereas the lowest amount was observed at $\mathrm{pH}$ levels of 6.0 and 8.0. Furthermore, the lowest and the highest bacterial growth levels were associated with the $\mathrm{pH}$ levels of 7.0, 5.0 and 6.0, respectively, $24 \mathrm{~h}$ after the inoculation.

In terms of the effects of various temperatures, the paired-samples t-test results confirmed a significant rise in the bacterial growth rate during inoculation and $24 \mathrm{~h}$ later $(\mathrm{p}<0.05)$. On the other hand, the one-way ANOVA results indicated no significant difference between various temperatures with regard to bacterial growth rate $(p>0.05)$. Meanwhile, there was a significant difference between various temperatures $24 \mathrm{~h}$ after the inoculation $(p<0.05)$. According to the obtained results, the highest bacterial growth rates were observed at 20, 25 , and $35^{\circ} \mathrm{C}$ temperatures, whereas the lowest growth rate was detected at $40^{\circ} \mathrm{C}$.

Concerning the effects of various $\mathrm{NaCl}$ concentrations, the paired-samples t-test results demonstrated a significant decline in the bacterial growth rate during the inoculation and $24 \mathrm{~h}$ later in the presence of different $\mathrm{NaCl}$ concentrations (1, 3, and $5 \%)(p<0.05)$. Accordingly, there was a significant difference between various $\mathrm{NaCl}$ concentrations during the inoculation and $24 \mathrm{~h}$ later in terms of the bacterial growth rate. In this regard, the highest bacterial growth rate was related to $3 \% \mathrm{NaCl}$ concentration during the inoculation, whereas the lowest level was observed at $1 \% \mathrm{NaCl}$ concentration. Moreover, the highest and the lowest bacterial growth rates were related to 3 and $5 \%$ $\mathrm{NaCl}$ concentrations, respectively, $24 \mathrm{~h}$ following the inoculation.

Regarding the effects of UV light exposure time, the results indicated a decreased bacterial growth rate in all times (30, 60, and $90 \mathrm{~s}$ ) during $24 \mathrm{~h}$ after the inoculation $(p<0.05)$. Furthermore, the one-way ANOVA results showed no significant difference between various UV light exposure times in terms of the bacterial growth rate during $24 \mathrm{~h}$ following the inoculation ( $\mathrm{p}>0.05$ ). Moreover, $24 \mathrm{~h}$ after the inoculation, the highest and the lowest growth rates related to UV light exposure times were reported by 30 and $90 \mathrm{~s}$, respectively.
Expression of Pathogenic Genes
after Environmental Stresses

pH Levels

The RT-PCR was performed on three strains of $A$. butzleri at the $\mathrm{pH}$ levels of 5.0-9.0 using the specific primers of $C i a B_{1}, C i a B_{2}, m v i N_{1}, m v i N_{2}, t l y A_{1}$, and $t l y A_{2}$. In this regard, the proliferation of 284,290 and $230 \mathrm{bp}$ segments confirmed the expression of $c i a B, m v i N$, and tlyA pathogenic genes, respectively. Moreover, their lack of proliferation approved no expression of the mentioned genes. Accordingly, all three ciaB, mviN, and tly $A$ pathogenic genes were expressed in bacterium No. 1 at all pH levels (viz. 5.0-9.0) (Fig. 5). On the other hand, the $c i a B$ gene was expressed in bacterium No. 2 only at the $\mathrm{pH}$ levels of 7.0 and 8.0. The $m v i N$ gene was further expressed only at the $\mathrm{pH}$ level of 7.0, whereas the $\operatorname{tly} A$ gene was expressed just at the $\mathrm{pH}$ levels of 7.0 and 8.0 (Fig. 6). In bacterium No. 3, the ciaB and $m v i N$ genes were expressed only at the $\mathrm{pH}$ levels of 6.0, 7.0 and 8.0, and the tly $A$ gene was expressed merely at the $\mathrm{pH}$ levels of 6.0 and 7.0 (Fig. 7).

\section{Temperature}

The RT-PCR was practiced on three strains of $A$. butzleri at different temperatures of 35, 30, 25, 20, and $40^{\circ} \mathrm{C}$ using the specific primers of $\mathrm{Cia} B_{1}, \mathrm{Cia} B_{2}, \mathrm{mviN}_{1}$, $m v i N_{2}, t l y A_{1}$, and $t l y A_{2}$. In this study, the ciaB gene was expressed only at 35,30 , and $20^{\circ} \mathrm{C}$ in $1-3$ bacteria, respectively. Moreover, the $m v i N$ gene was expressed at $40,35,30$, and $20^{\circ} \mathrm{C}$, whereas the tly $A$ gene was expressed only at 35,30 , and $25^{\circ} \mathrm{C}$ (Figs $8-10$ ).

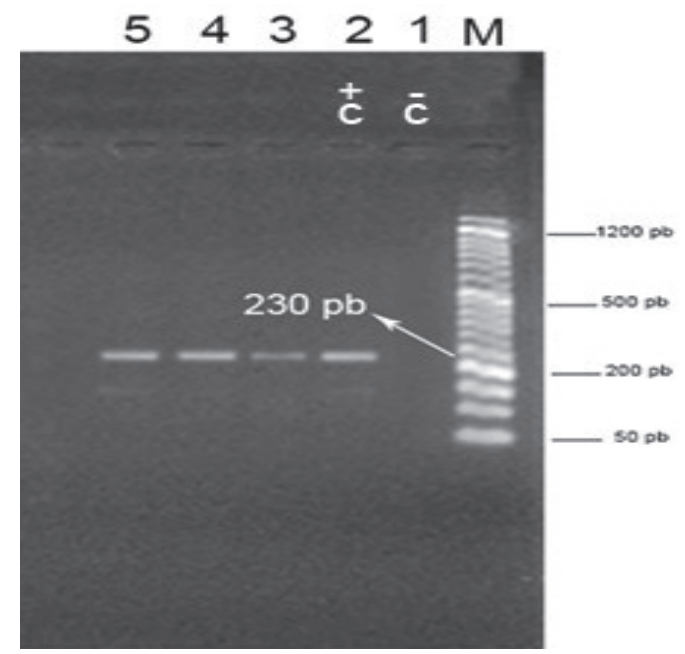

Fig. 4. Results of PCR on 1.5\% agarose gel, Lane 1, negative control, Lane 2, positive control (a strain confirmed in previous studies), Lanes 3-5, one-third of samples of A. butzleri that contained the tlyA gene. M, Marker (1.5-kilo bp). 


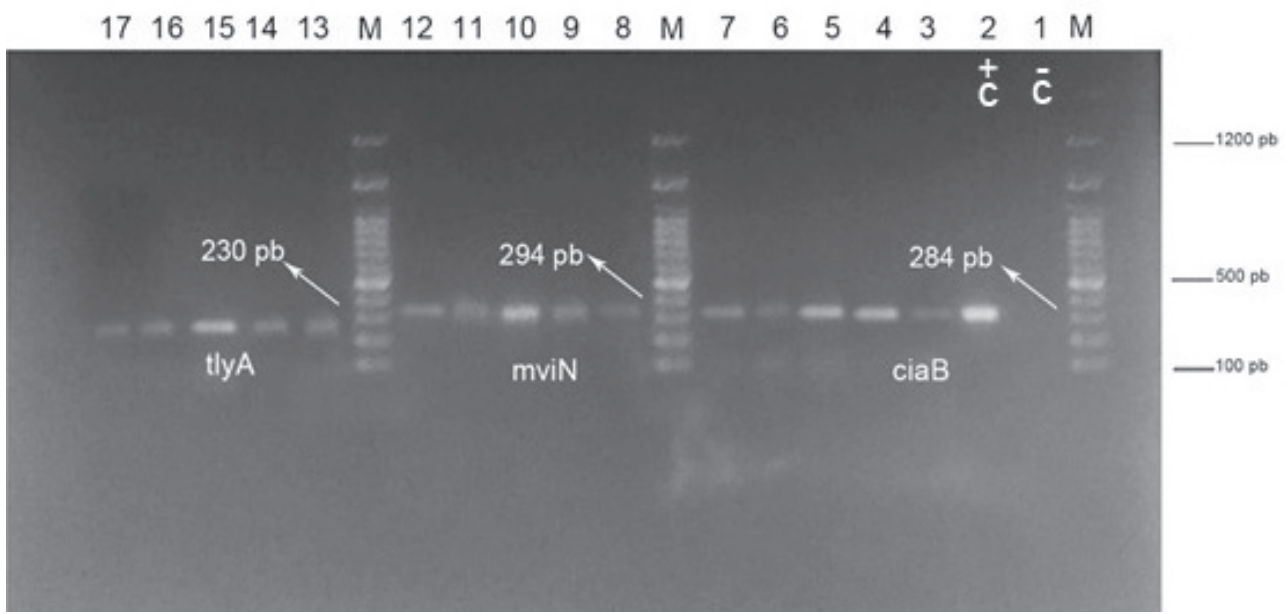

Fig. 5. Results of RT-PCR on 1.5\% agarose gel following the effect of different $\mathrm{pH}$ levels in sample No. 1. From the right side, Lane 1, negative control, Lane 2, positive control, Lanes 3-7, the ciaB gene at $\mathrm{pH}$ levels of 5.0-9.0, respectively, Lanes 8-12, the $m v i N$ gene at $\mathrm{pH}$ levels of 5.0-9.0, respectively, Lanes 13-17, the tlyA gene at $\mathrm{pH}$ levels of 5.0-9.0, respectively. M, Marker (1-kilo bp).

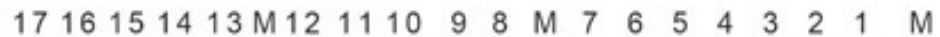

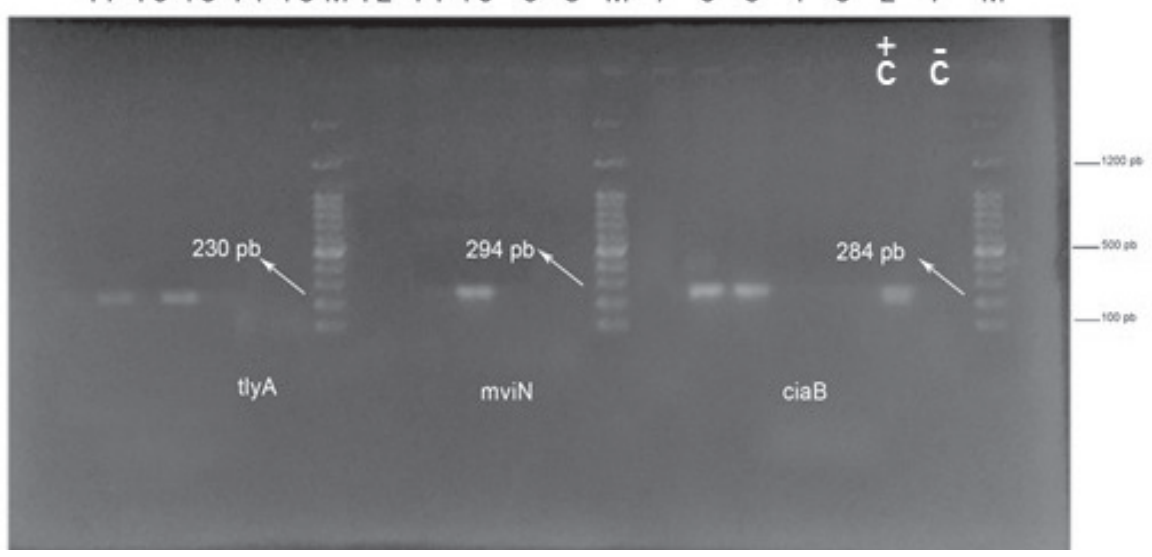

Fig. 6. Results of RT-PCR on $1.5 \%$ agarose gel following the effect of different $\mathrm{pH}$ levels in sample No. 2. From the right side Lane 1 , negative control, Lane 2, positive control, Lanes 3-7, the ciaB gene at $\mathrm{pH}$ levels of 5.0-9.0, respectively, Lanes 8-12, the $m v i N$ gene at $\mathrm{pH}$ levels of 5.0-9.0, respectively, Lanes 13-17, the tlyA gene at $\mathrm{pH}$ levels of 5.0-9.0, respectively. M, Marker (1-kilo bp).

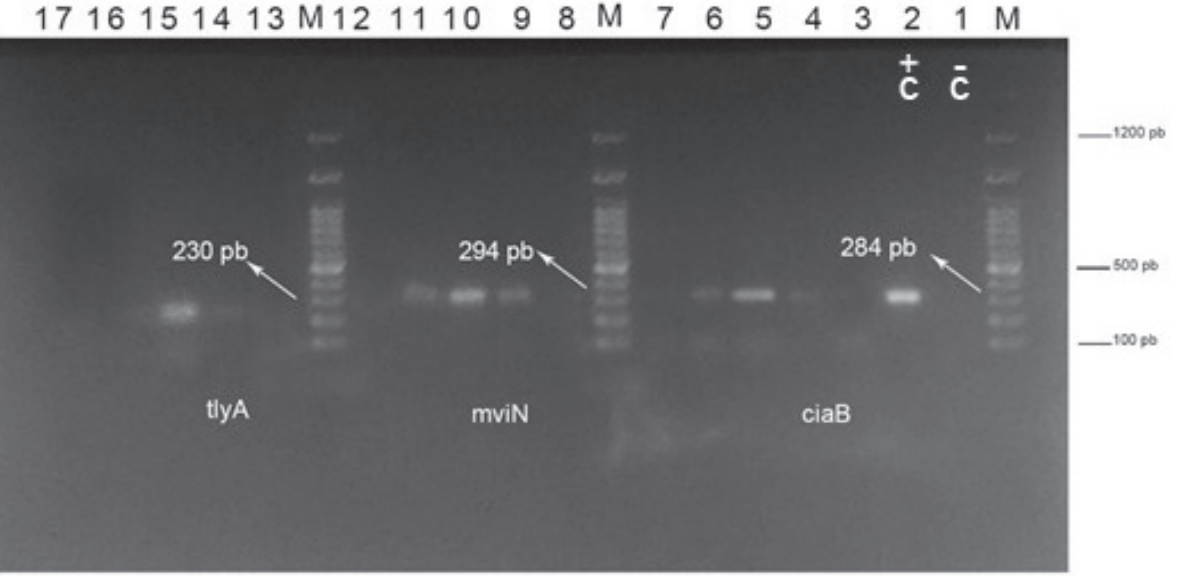

Fig. 7. Results of RT-PCR on $1.5 \%$ agarose gel following the effect of different $\mathrm{pH}$ levels in sample No. 3. From the right side Lane 1 , negative control, Lane 2, positive control, Lanes 3-7, the ciaB gene at $\mathrm{pH}$ levels of 5.0-9.0, respectively, Lanes 8-12, the $m v i N$ gene at $\mathrm{pH}$ levels of 5.0-9.0, respectively, Lanes 13-17, the tlyA gene at $\mathrm{pH}$ levels of 5.0-9.0, respectively. M, Marker (1-kilo bp). 
$\begin{array}{lllllllllllllllllllll}17 & 16 & 15 & 14 & 13 & \mathrm{M} & 12 & 11 & 10 & 9 & 8 & \mathrm{M} & 7 & 6 & 5 & 4 & 3 & 2 & 1 & \mathrm{M}\end{array}$

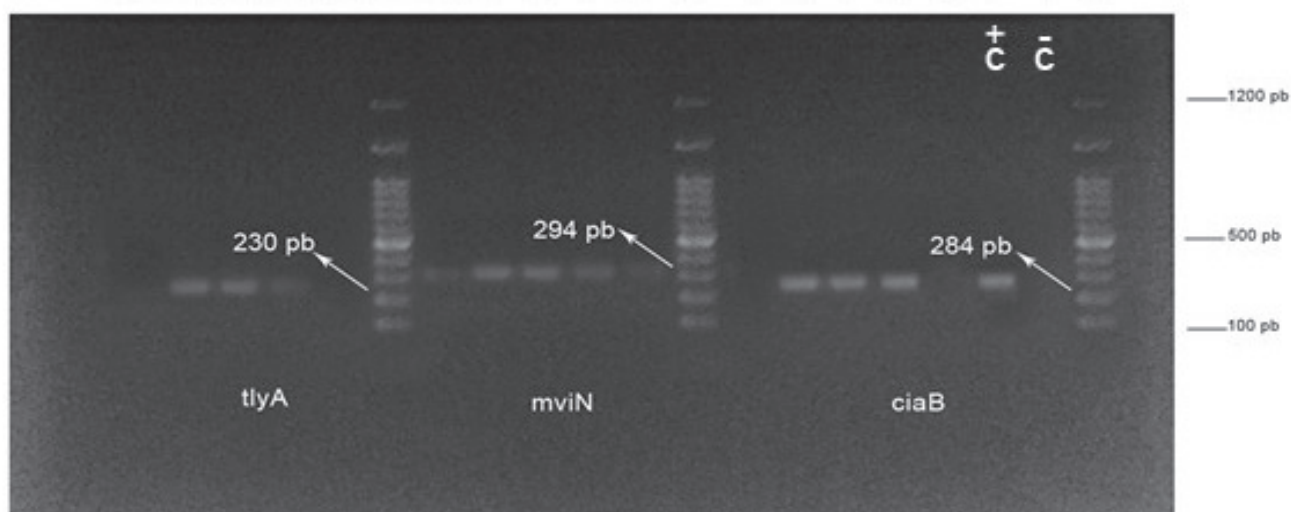

Fig. 8. Results of RT-PCR on $1.5 \%$ agarose gel following the effect of different temperatures in sample No. 1. From the right side, Lane 1, negative control, Lane 2, positive control, Lanes 3-7, the ciaB gene at different temperatures of 20, 25, 30, 35, and $40^{\circ} \mathrm{C}$, respectively, Lanes 8-12, the $m v i N$ gene at different temperatures of $20,25,30,35$, and $40^{\circ} \mathrm{C}$, respectively, Lanes $13-17$, the $t l y A$ gene at different temperatures of $20,25,30,35$, and $40^{\circ} \mathrm{C}$, respectively. M, Marker (1-kilo bp).

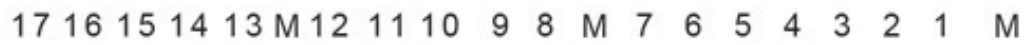

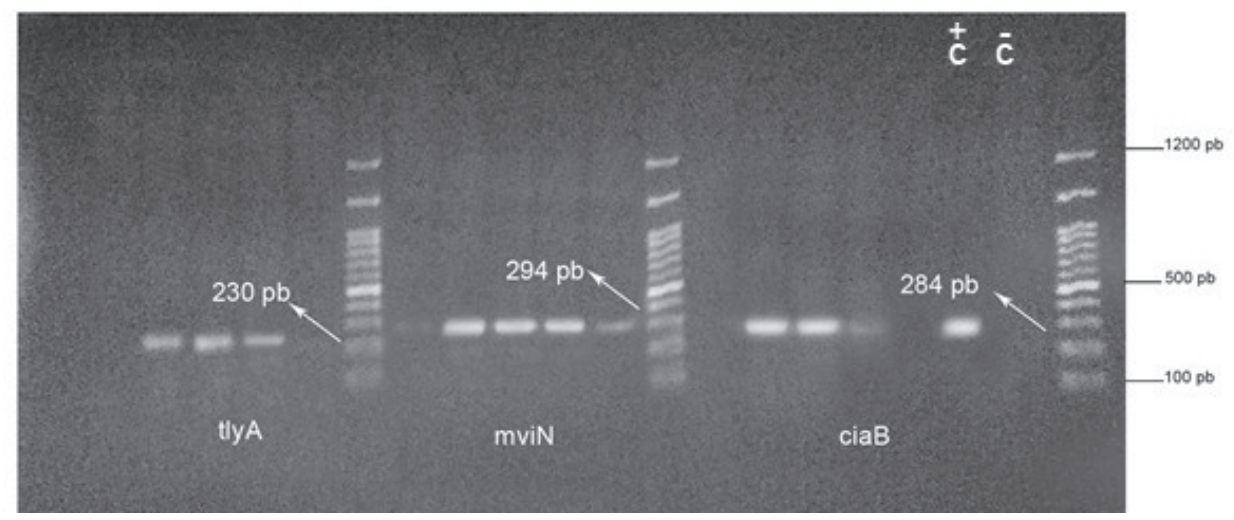

Fig. 9. Results of RT-PCR on $1.5 \%$ agarose gel following the effect of different temperatures in sample No. 2. From the right side, Lane 1, negative control, Lane 2, positive control, Lanes 3-7, the ciaB gene at different temperatures of $20,25,30,35$, and $40^{\circ} \mathrm{C}$, respectively, Lanes 8-12, the $m v i N$ gene at different temperatures of $20,25,30,35$, and $40^{\circ} \mathrm{C}$, respectively, Lanes $13-17$, the $t l y A$ gene at different temperatures of $20,25,30,35$, and $40^{\circ} \mathrm{C}$, respectively. M, Marker (1-kilo bp).

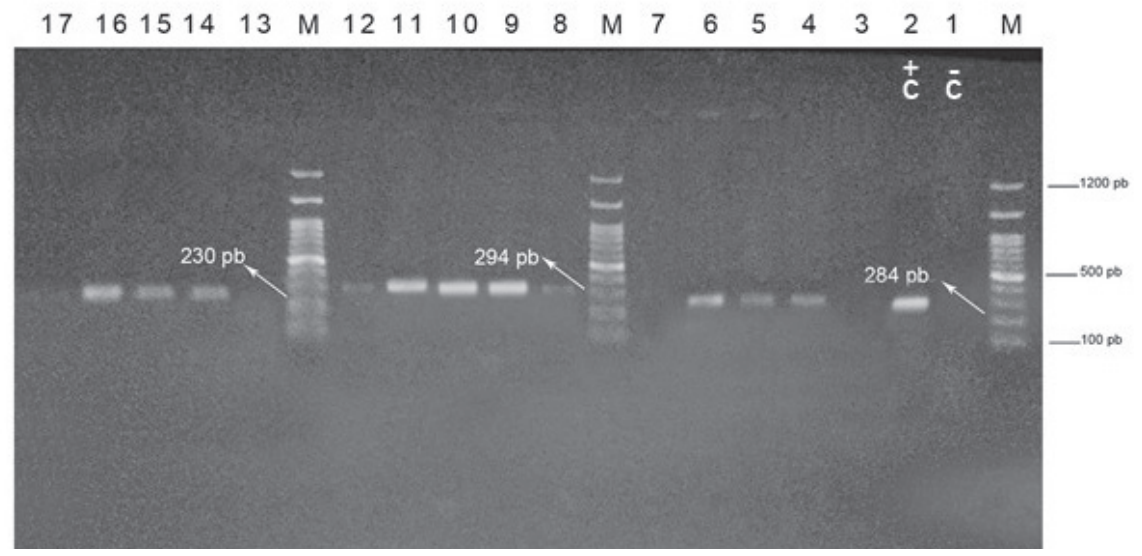

Fig. 10. Results of RT-PCR on 1.5\% agarose gel following the effect of different temperatures in sample No. 3. From the right side, Lane 1, negative control, Lane 2, positive control, Lanes 3-7, the ciaB gene at different temperatures of 20, 25, 30, 35, and $40^{\circ} \mathrm{C}$, respectively, Lanes 8-12, the $m v i N$ gene at different temperatures of $20,25,30,35$, and $40^{\circ} \mathrm{C}$, respectively, Lanes $13-17$, the tly $A$ gene at different temperatures of $20,25,30,35$, and $40^{\circ} \mathrm{C}$, respectively. M, Marker (1-kilo bp). 


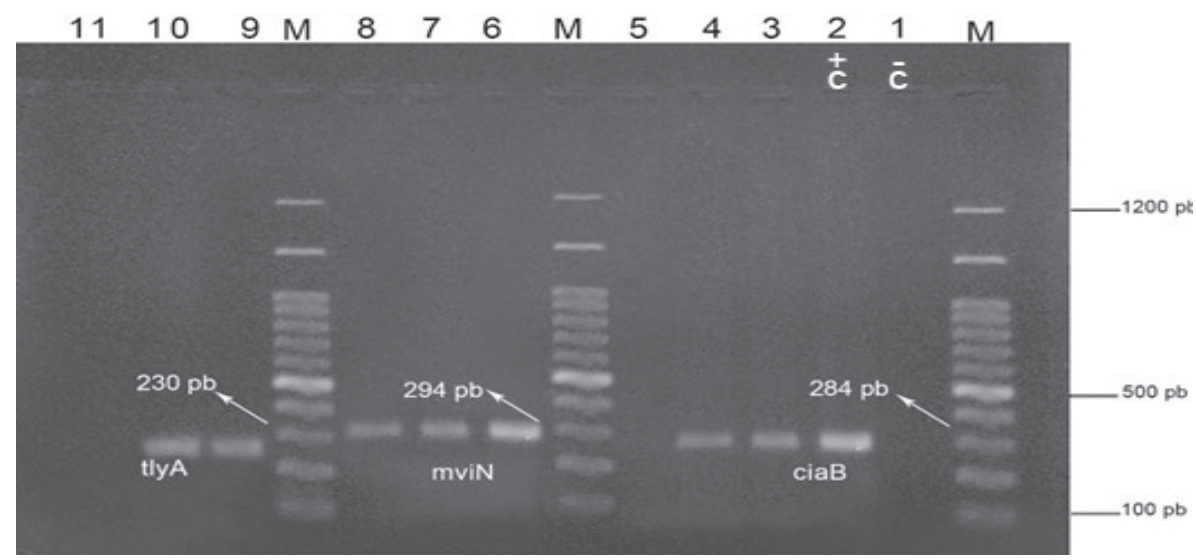

Fig. 11. Results of RT-PCR on $1.5 \%$ agarose gel following the effect of different $\mathrm{NaCl}$ concentrations in sample No. 1. From the right side, Lane 1, negative control, Lane 2, positive control, Lanes 3-5, the ciaB gene at 1, 3, and 5\% $\mathrm{NaCl}$ concentrations, respectively, Lanes 6-8, the $m v i N$ gene at 1,3 , and $5 \% \mathrm{NaCl}$ concentrations, respectively, Lanes $9-11$, the tly $\mathrm{A}$ gene at 1,3 , and $5 \% \mathrm{NaCl}$ concentrations, respectively. M, Marker (1-kilo bp).

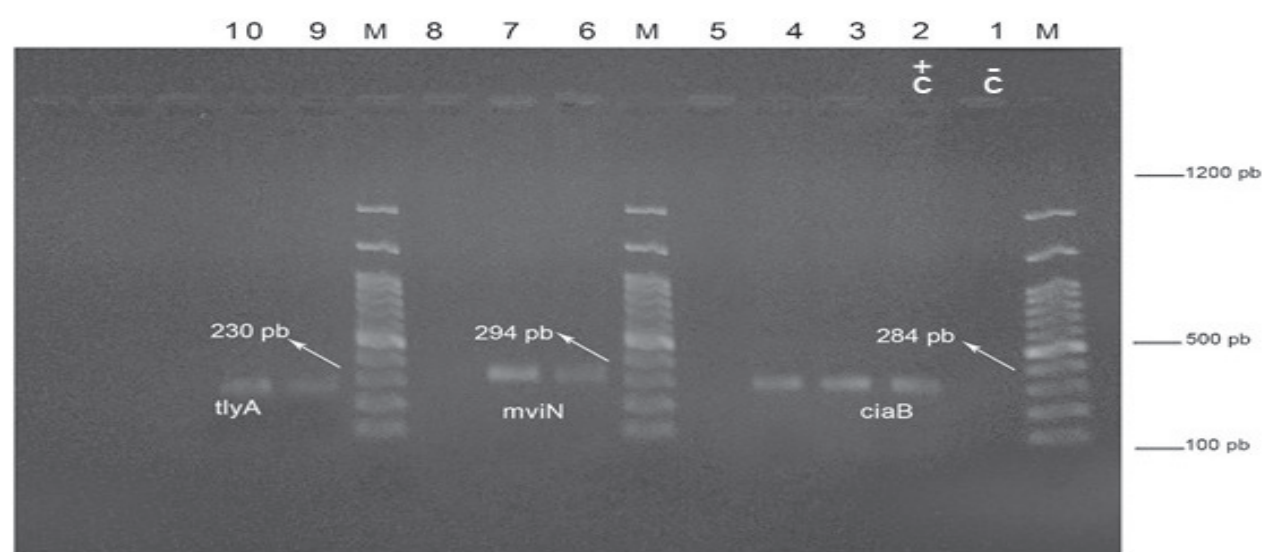

Fig. 12. Results of RT-PCR on $1.5 \%$ agarose gel following the effect of different $\mathrm{NaCl}$ concentrations in sample No. 2. From the right side, Lane 1, negative control, Lane 2, positive control, Lanes 3-5, the ciaB gene, Lanes 6-8, the mviN gene, Lanes 9-11, the tlyA gene. M, Marker (1-kilo bp).

\section{$\mathrm{NaCl}$ Concentrations}

The RT-PCR was performed on three strains of A. butzleri at different $\mathrm{NaCl}$ concentrations (viz. 1, 3, and 5\%) using the specific primers of $\mathrm{Cia} B_{1}$, $C i a B_{2}, m v i N_{1}, m v i N_{2}, t l y A_{1}$, and tly $A_{2}$. The ciaB gene was also expressed in bacteria No. 1 and 3 at $\mathrm{NaCl}$ concentrations of 1 and $3 \%$ but it was not expressed at $5 \%$ concentration. On the other hand, the mviN gene was expressed at all $\mathrm{NaCl}$ concentrations and the tly $\mathrm{A}$ gene was simply expressed at 1 and $3 \%$ concentrations (Figs 11 and 12). In bacterium no. 2, all three tly $A, c i a B$, and $m v i N$ pathogenic genes were expressed at 1 and $3 \%$ $\mathrm{NaCl}$ concentrations and none of them was expressed at $5 \%$ concentration (Fig. 13).

\section{UV Light Exposure Time}

The RT-PCR was done at different UV light exposure times using the specific primers. All three tly $A, c i a B$, and $m v i N$ pathogenic genes were accordingly expressed only at 30 and $60 \mathrm{~s} \mathrm{UV} \mathrm{light} \mathrm{exposure} \mathrm{times}$ in bacterium No. 1 (Fig. 14). Meanwhile, the ciaB and $m v i N$ genes were expressed only at 30 and $60 \mathrm{~s}$ UV light exposure times in bacterium no. 2 and the tlyA gene was expressed only at $30 \mathrm{~s}$ exposure time (Fig. 15). In bacterium no. 3, the $c i a B$ and tly $A$ genes were also expressed only at 30 and $60 \mathrm{~s}$ UV light exposure times, whereas the mviN gene was expressed at all 30, 60, and $90 \mathrm{~s}$ exposure times (Fig. 16).

To date, no adequate information has been reported about A. butzleri pathogenic mechanisms (e.g., adhesion, invasion, or toxicity). The global prevalence of $A$. butzleri infection is also unclear since no conventional diagnostics methods have been implemented for the bacterium concerned. There is no doubt that $A$. butzleri strains have pathogenic effects on humans. Nevertheless, further clinical observations are required to determine the interference of $A$. butzleri strains in human infections [16]. The association of 


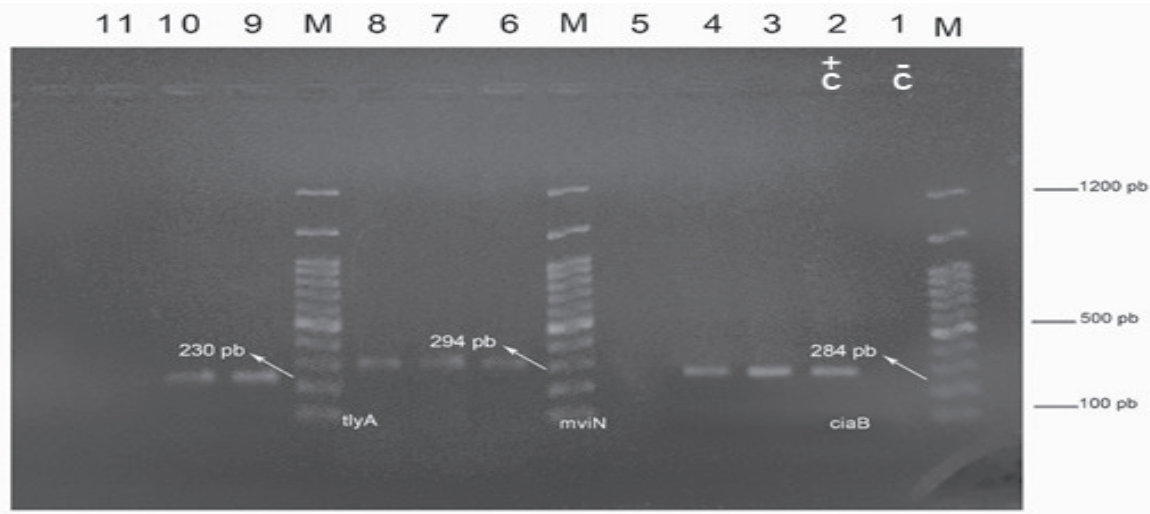

Fig. 13. Results of RT-PCR on $1.5 \%$ agarose gel following the effect of different $\mathrm{NaCl}$ concentrations in sample No. 3. From the right side, Lane 1, negative control, Lane 2, positive control, Lanes 3-5, the ciaB gene, Lanes 6-8, the $m v i N$ gene, Lanes 9-11, the tlyA gene, M, Marker (1-kilo bp).

A. butzleri species with human pathogenesis, as well as their discovery and spread in food and water, has also confirmed the necessity of further studies on the survival rates of this microorganism, as well as the search for new therapies to control and eliminate this bacterium. The significant survival of $A$. butzleri on the plastic surface can be similarly a factor in the transmission of this bacterium to humans during food processing [17].

Most studies on the prevalence of $A$. butzleri are related to poultry feed, which has the highest rate, followed by pork products and raw milk $[18,19]$. In the case of poultry, there are still debates about the sources of contamination, as some researchers believe that the environment of slaughterhouses, not their wastes, has been the main source due to no ability to isolate A. butzleri from the feces. However, some researchers have established that the bacteria could be living in the intestines of poultry, demonstrating that factors such as animals, samples, and methods applied have affected the evaluation and the identification of the prevalence rate of the given bacterium [9]. The high resistance of
A. butzleri, along with its ability to survive and grow in aerobic conditions, has also increased its potential as a food- and water-borne pathogen. On the other hand, its adaptability to stressful situations may later make it resistant to this or other types of stress. Therefore, exposure to various stresses during a lifecycle creates its survival rate in the food strain [7].

Since most bacteria deal with environmental stresses during long periods of their lives, more information and findings in this regard as well as associated responses are required to understand their physiology. This can further reduce the levels of contamination in environmental samples such as poultry slaughterhouse wastewater to prevent the spread of bacteria to the environment and its transmission to humans. It also leads to the development of new methods for environmental health, veterinary medicine, treatment of diseases, as well as introduction of new antimicrobial agents. Therefore, studying responses to stresses will be a new topic in biological and applied research.

In the present study, poultry slaughterhouse wastewater, culture techniques, and the PCR/RT-PCR

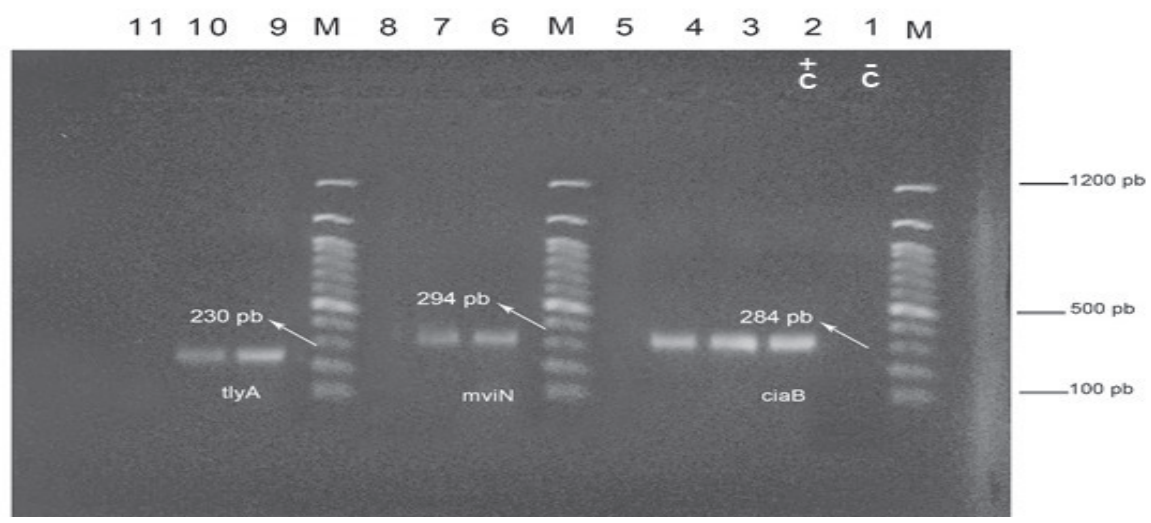

Fig. 14. Results of RT-PCR on $1.5 \%$ agarose gel following the effect of 30, 60, and $90 \mathrm{~s}$ UV light exposure times in sample No. 1. From the right side, Lane 1, negative control, Lane 2, positive control, Lanes 3-5, the ciaB gene at 30, 60, and $90 \mathrm{~s}$ UV light exposure times, respectively, Lanes 6-8, the $m v i N$ gene at 30,60, and $90 \mathrm{~s}$ UV light exposure times, respectively, Lanes 9-11, the tly $A$ gene at 30, 60, and $90 \mathrm{~s}$ UV light exposure times, respectively. M, Marker (1-kilo bp). 


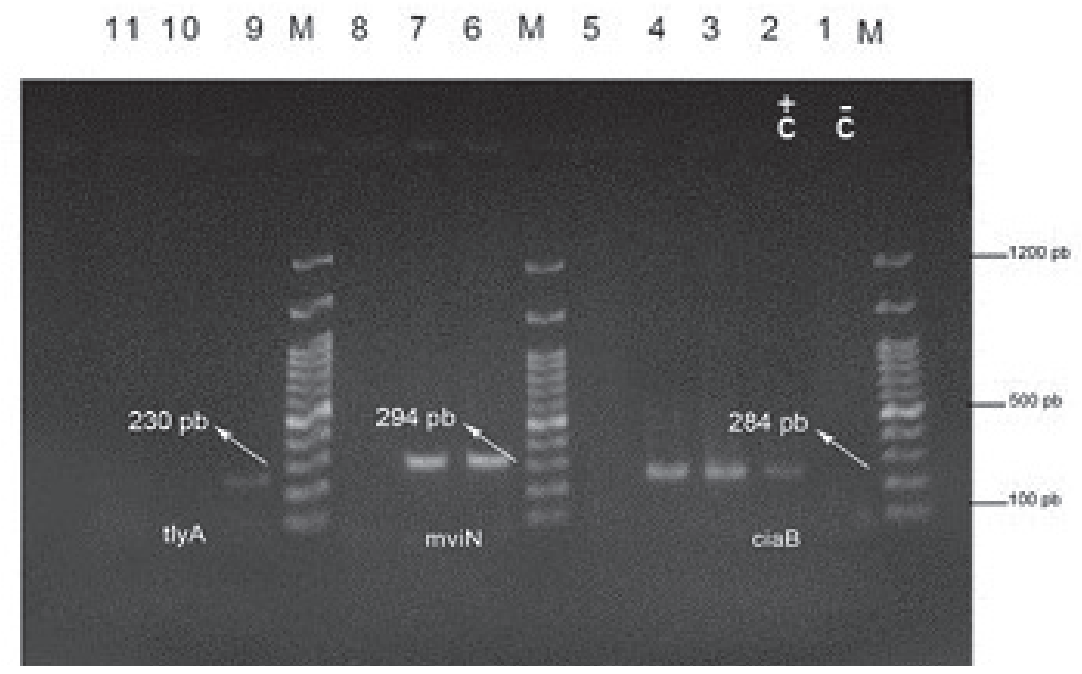

Fig. 15. Results of RT-PCR on 1.5\% agarose gel following the effect of 30, 60, and $90 \mathrm{~s}$ UV light exposure times in sample No. 2. From the right side, Lane 1, negative control, Lane 2, positive control, Lanes 3-5, the ciaB gene at 30, 60, and $90 \mathrm{~s}$ UV light exposure times, respectively, Lanes 6-8, the $m v i N$ gene at 30,60, and $90 \mathrm{~s} \mathrm{UV} \mathrm{light} \mathrm{exposure} \mathrm{times,} \mathrm{respectively,} \mathrm{Lanes} \mathrm{9-11,} \mathrm{the} t l y A$ gene at 30, 60, and $90 \mathrm{~s}$ UV light exposure times, respectively. M, Marker (1-kilo bp).

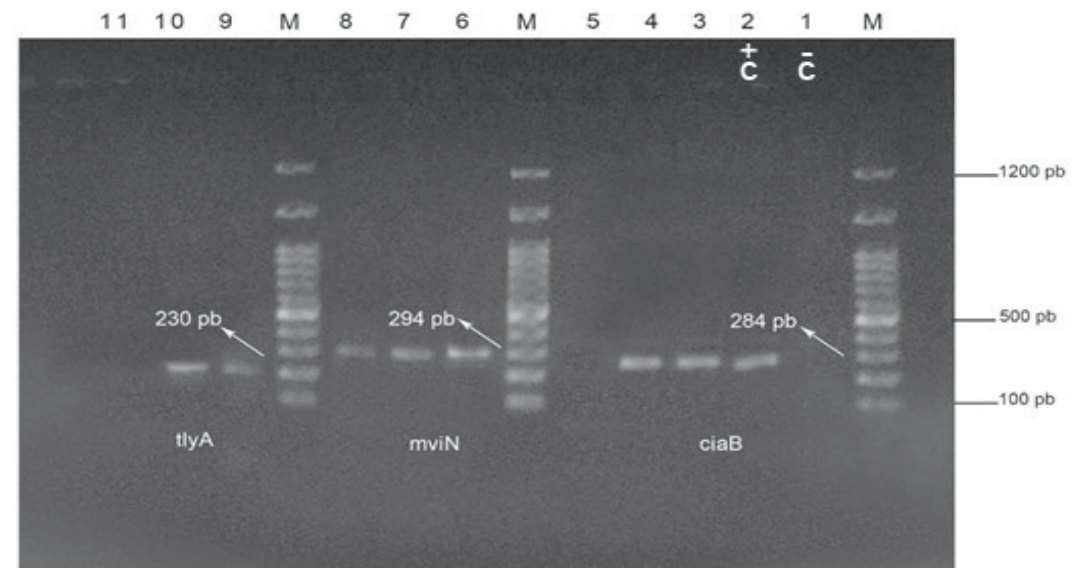

Fig. 16. Results of RT-PCR on 1.5\% agarose gel following the effect of 30, 60, and $90 \mathrm{~s}$ UV light exposure times in sample No. 3. From the right side, Lane 1, negative control, Lane 2, positive control, Lane 3-5, the ciaB gene at 30, 60, and $90 \mathrm{~s} \mathrm{UV} \mathrm{light} \mathrm{exposure} \mathrm{times,}$ respectively, Lanes 6-8, the $m v i N$ gene at 30,60, and $90 \mathrm{~s}$ UV light exposure times, respectively, Lanes 9-11, the tly $\mathrm{A}$ gene at 30, 60, and $90 \mathrm{~s}$ UV light exposure times, respectively. M, Marker (1-kilo bp).

were applied to isolate and identify A. butzleri. Overall, 58 A. butzleri samples were identified among 384 cases. Similarly, Ghane et al. (2012) had identified 15 strains of $A$. butzleri using the same methods [20]. The samples could be thus affected by environmental factors; therefore, a change of seasons was taken into account and the prevalence of this bacterium in different seasons of the year was examined. In the springtime, five strains of $A$. butzleri with a frequency of $8.62 \%$ were isolated from the Cheshmeh Kileh River, whereas 20 strains with a frequency of $34.48 \%$ were isolated from wastewater discharged by the poultry slaughterhouse.

In the summer, two strains of $A$. butzleri with a frequency of $3.44 \%$ were also isolated from the Cheshmeh Kileh River, but eight strains with a frequency of $13.79 \%$ were isolated from the poultry slaughterhouse wastewater. In fall, nine strains of A. butzleri with a frequency of $15.51 \%$ were similarly isolated from the Cheshmeh Kileh River, whereas 11 strains with a frequency of $18.96 \%$ were isolated from the poultry slaughterhouse wastewater. In the wintertime, three strains of $A$. butzleri with a frequency of $5.17 \%$ were also isolated from the Cheshmeh Kileh River, while no strains were isolated from the poultry slaughterhouse wastewater. As such, the results of the present study showed that different seasons were of utmost importance in isolating this bacterium and the highest rate of isolation of $A$. butzleri with a frequency of $43.1 \%$ had occurred in the springtime. Similar results had been correspondingly reported 
by Collado et al. (2010) [21], Ghorbani et al. (2014) [22], and Ghaju Shrestha et al. (2019) [23].

As some bacteria may lose their pathogenicity, after the induction of some stresses, or at least their pathogenicity may significantly reduce, the study findings could be utilized to evaluate various effects of environmental stresses on the growth rate and expression of these bacteria and to find proper solutions to control their transmission. In addition, fundamental research would be carried out on some topics, not sufficiently covered.

In the present research, various physicochemical conditions were further applied to three strains of A. butzleri, which confirmed the presence of mviN, $c i a B$ and tlyA pathogenic genes based on the PCR/RTPCR. According to the results of the present study, the lowest bacterial growth rate after $24 \mathrm{~h}$ was related to the $\mathrm{pH}$ levels of 5.0 and 6.0, which was consistent with the findings obtained by Lee and Choi (2013) [15] and Young Park and Do Ha (2015) [1]. The lowest bacterial growth rate was related to $5 \% \mathrm{NaCl}$ concentration and 90 s UV light exposure time. In this line, Young Park and Do Ha (2012) had further reported a descending trend in the growth rate of $A$. butzleri at $\geq 4 \% \mathrm{NaCl}$ concentration.

The main objective of the present study was to discontinue the expression of tly,$c i a B$, and $m v i N$ pathogenic genes of $A$. butzleri by applying various stresses. As mentioned before, the RT-PCR was applied to evaluate the expression/lack of expression of the mentioned genes. Overall, the study results showed that the $c i a B$ gene expression was prevented at the $\mathrm{pH}$ levels of 5.0, 6.0, and 9.0 , at 20 and $40^{\circ} \mathrm{C}$, at $5 \%$ $\mathrm{NaCl}$ concentration, and at $90 \mathrm{~s}$ UV light exposure time. In addition, the mviN gene expression was discontinued at the $\mathrm{pH}$ levels of 5.0, 6.0, 8.0, and 9.0 at $5 \% \mathrm{NaCl}$ concentration, at oxygen concentration of $180 \mathrm{rpm}$, and at $90 \mathrm{~s}$ UV light exposure time. Moreover, the tly $A$ gene expression was prevented at the pH levels of 5.0, 6.0, 8.0, and 9.0, at 20 and $40^{\circ} \mathrm{C}$, at $5 \% \mathrm{NaCl}$ concentration, and at 60 and 90 s UV light exposure times. As no research has so far been conducted, to the best of authors' knowledge, on the effect of environmental stresses on the expression of $A$. butzleri pathogenic genes this study could be the first attempt in biological and applied research on bacteria.

\section{Conclusion}

According to the results of the present study, $A$. butzleri was found in the poultry slaughterhouse wastewater and the Cheshmeh Kileh River, and the highest amount of the bacteria isolated was related to the wastewater in springtime. The results also indicated the presence of all $\operatorname{tly} A, c i a B$, and $m v i N$ pathogenic genes in all $A$. butzleri strains. These data suggested that $A$. butzleri might endanger human health because the presence of pathogenic genes could be a potential risk factor for the bacterium. Invasive diseases caused by $A$. butzleri could be thus a serious threat to individuals with impaired immune systems.

The results of the effect of various environmental stresses on the expression of pathogenic genes correspondingly demonstrated that the expression of tly $A$, ciaB, and $m v i N$ genes discontinued at the $\mathrm{pH}$ levels of 5.0, 6.0, and 9.0 , at $5 \% \mathrm{NaCl}$ concentration, at oxygen concentration of $180 \mathrm{rpm}$, and $90 \mathrm{~s}$ UV light exposure time. Furthermore, the tly $A$ and $c i a B$ gene expression stopped at 20 and $40^{\circ} \mathrm{C}$, while temperature had no impact on the expression of the mviN gene. The study also revealed that the expression of the pathogenic genes was prevented while the bacterial growth rate increased due to the effect of temperature. The study findings could be a proper solution to discontinue the transmission of the bacterium through poultry slaughterhouse wastewater and rivers. In addition, they could be applied to improve microbiological quality of food. Furthermore, an effective step could be taken to determine the proper treatment of diseases induced by A. butzleri.

\section{Acknowledgements}

The authors hereby extend their gratitude to the Vice Chancellor's Office for Research (grant no. 16330507941021) at Islamic Azad University (IAU), Shiraz Branch, Shiraz, Iran. They also sincerely appreciate the employees of the Microbiology Research Laboratory at IAU, Tonekabon Branch, Tonekabon, Iran.

\section{Conflict of Interest}

The authors declare no conflict of interest.

\section{References}

1. YOUNG PARK S., DO HA S. Development of an absorbance-based response model for monitoring the growth rates of Arcobacter butzleri as a function of temperature, $\mathrm{pH}$, and $\mathrm{NaCl}$ concentration. Poultry Science, 94, 136, 2015.

2. BADILLA-RAMÍREZ Y., FALLAS-PADILLA K.L., FERNÁNDEZ-JARAMILLO H., ARIAS-ECHANDI M. L. Survival capacity of Arcobacter butzleri inoculated in poultry meat at two different refrigeration temperatures. Rev Inst Med Trop Sao Paulo, 58, 22, 2016.

3. HO H.T., LIPMAN L.J., GAASTRA W. Arcobacter, wath is know and unknowm about a potential foodborne zoonotic agent. Vat. Microbiol, 115, 1, 2006.

4. KARADAS G., SHARBATI S., HANEL I., MESSELHAUBER U., GLOCKER E., ALTER T., GOLZ G. Presence of virulence genes, adhesion and invasion of Arcobacter butzleri. J Appl Microbiol, 115, 583, 2013. 
5. FIGUERAS M.J., COLLADO L., LEVICAN A., PEREZ J., SOLSONA M.J., YUSTES C. Arcobacter molluscorum sp. nov., a new species isolated from shellfish. Syst Appl Microbiol, 34, 105, 2011.

6. SASI T.S., RAHUL K., RAMAPRASAD E.V., SASICALA CH., RAMANA CH.V. Arcobacter anaerophilus sp. nov., isolated from an estuarine sediment andemended description of the genus Arcobacter. Int J Syst Evol Microbiol, 63, 4619, 2013.

7. ISOHANNI P., HUEHN S., AHO T., ALTER T., LYHS U. Heat stress adaptation induces cross-protection against lethal acid stress conditions in Arcobacter butzleri but not in Campylobacter jejuni. Food Microbiol, 34, 431, 2013.

8. D SA E.M., HARRISON M.A. Effect of $\mathrm{pH}, \mathrm{NaCl}$ content, and temperature on growth and survival of Arcobacter spp. J. Food Prot, 68, 18, 2005.

9. COLLADO L., FIGUERAS M.J. Taxonomy, epidemiology, and clinicalrelevance of the genus Arcobacter. Clin Microbiol, Rev 24, 174, 2011.

10. FERREIRA S., QUEIROZ J.A., OLEASTRO M., DOMINGUES F.C. Insights in the pathogenesis and resistance of Arcobacter, A review. Critical Reviews in Microbiology, Early Online: 1, 2015.

11. MILLER W.G., TOH H., SHARMA V.K., OSHIMA K., HATTORI M., WARD F.B., FREE A., TYLOR T.D. The complete genome sequenceand analysis of the epsilonproteobacterium Arcobacter butzleri. PLOS One, 2, 1358, 2007.

12. DOUIDAH L., DE ZUTTER L., BARE J., DE VOS P., VANDAMME P., VANDENBERG O., VAN DEN ABEELE A.M., HOUF K. Occurrence of putative virulence genes in Arcobacter species isolated from humans andanimals. J Clin Microbiol, 50, 735, 2012.

13. ATABAY H.I., CORRY J.E.I. The prevalence of Campylobacter and Arcobacter in chickens. Journal of Applied Microbiology, 83, 619, 1997.

14. TABATABAEI M., SHIRZAD ASKI H., SHAYEGH H., KHPSHBAKHT R. Occurrence of six virulenceassociated genes in Arcobacter species isolated from various sources in Shiraz, Southern Iran. Microbial Pathogenesis, 66, 1, 2014.
15. LEE M.H., CHOI C. Survival of Arcobacter butzleri in apple and pear purees. J Food Safety, 33, 333, 2013.

16. LEVICAN A., COLLADO L., FIGUERA, M.J. Arcobacter cloacae sp. nov. and Arcobacter suis sp. nov., two new species isolated from food and sewage. Syst Appl Microbiol, 36, 22, 2013.

17. CERVENKA L., KRISTLOVA J., PESKOVA I., VYTRASOVA J., PEJCHALOVA M., BROZKOVA I. Persistence of Arcobacter butzleri CCUG 30484 on plastic, stainless steel and glass surfaces. Braz J Microbiol, 39, $517,2008$.

18. COLLADO L., GUARRO J., FIGUERAS M. J. Prevalence of Arcobacter in Meat and Shellfish. J Food Protect, 72, $1102,2009$.

19. FIGUERAS M..J., LEVICAN A., PUJOL I., BALLESTER F., RABADA QUILEZ M.J., GOMEZ-BERTOMEU F. A severe case of persistentdiarrhoea associated with Arcobacter cryaerophilus but attributed to Campylobacter sp.and a review of the clinical incidence of Arcobacter spp. New Microbes New Infect, 2, 31-7, 2014.

20. GHANE M., GHORBANI MOEIN F., MASSOUDIAN S. The First Isolation of Campylobacter jejuni from Caspian Sea's Water. Advance study in biology, 4 (9), 407, 2012.

21. COLLADO L., KASIMIR G., SAUTU U. P., BOSCH A., PINTO R.M., SAUCEDO G., HUGUET J., FIGUERAS M.J. Occurrence and diversity of Arcobacter spp. along the Llobregat River catchment, at sewageeffluents and in a drinking water treatment plant. Water Res 44, 3696, 2010.

22. GHORBANI F., GHANE M. Isolation of Arcobacter Butzleri from Caspian Sea's Water. Journal of Applied \& Environmental Microbiology, 2, (2), 61, 2014.

23. GHAJU SHRESTHA R., TANAKA Y., MALLA B., BHANDARI D., TANDUKAR S., INOUE D., SEI K., SHERCHAND J.B., HARAMOTO E. Identification of 16S rRNA and Virulence-Associated Genes of Arcobacter in Water Samples in the Kathmandu Valley, Nepal. Pathogens Open Access Journal, 8, 110; doi: 10.3390/ pathogens8030110, 2019. 